\title{
Hüperventilatsiooni ilmingud rituaalsetes tantsudes ${ }^{1}$
}

\begin{abstract}
Triinu Ojamaa
Teesid: Uurimuse aluseks on Alexander Theodor von Middendorffi andmed nganassaani rituaalsest karutantsust aastast 1884, Juri Simtšenko kirjeldus samast tantsust ja selle rituaalsest kontekstist aastast 1961 ning autori mitteautentses situatsioonis tehtud videosalvestis aastast 1989. Tantsu muusikaline saade koosneb karu urinat jäljendavatest kähisevatest helidest, mille oluline komponent on rütmiline ja kiire hingamine. Vastupidiselt tavapärasele laulmisele tuuakse helisid kuuldavale nii sisse kui ka välja hingates. Karutantsu tantsiti mõõdukas tempos ringis liikudes, see vältas tunde ja võis lõppeda tantsijate kokkuvarisemisega.

Gilbert Rouget uurimuses Music and Trance. A Theory of the Relations between Music and Possession esitatud kirjelduste põhjal on võimalik väita, et araabia maades viljeldavat dhikri (derviši rituaalne tegevus, mille lõppeesmärk võib olla kollektiivse transi saavutamine) saatev helind kõlab sarnaselt nganassaani tantsusaatega. Helind on seotud spetsiifilise hingamistehnikaga, mis seisneb pulmonaarse sisse- ja väljahingamise rütmilises vaheldumises.

See teadmus oli ajendiks artikli autori ja meditsiinidoktor Jaak Aru interdistsiplinaarsele uurimusele, tõestamaks püstitatud hüpoteesi, mille kohaselt tahtlikku hüperventileerimist ja sellega seonduvat hüpokapniat saab käsitleda teadvusekaotust põhjustava mehhanismina nganassaani rituaalse musitseerimise käigus. Karutantsu videosalvestuse analüüs ja hingamistsüklite kompuuteranalüüs näitab, et hüpoteesi võib pidada põhjendatuks.
\end{abstract}

Märksõnad: hüperventilatsioon, rituaalsed tantsud, nganassaani traditsiooniline kultuur

\section{Nganassaani tantsutraditsioonist}

Nganassaani tantsu on vähe uuritud, mistõttu sellest on ka vähe kirjutatud. Sellel võib olla kaks põhjust. Nii informantidelt tänapäeval saadud teave kui ka varasemad kirjalikud allikad näitavad, et nganassaanidel oligi ainult üks tants: see oli rituaalne tants, mida tantsiti kord aastas ühel teatud ööl. Seetõttu on uurijail olnud vähe võimalusi näha tantsu tantsimist, vähemalt 
autentses situatsioonis. Teiseks, kui vaadata asjale koreograafilisest aspektist, koosneb tants ülilihtsatest figuuridest, mistõttu see ei pruukinud uurijaile erilist huvi pakkuda. Sedalaadi ringtantse tantsitakse kogu maailmas.

Nganssaani tantsu kohta leidub andmeid Alexander Theodor von Middendorffi märkmetes, mis ta on kirja pannud 1884.-1885. aasta uurimisreisil Siberis (Middendorff 1953)² ning Juri Simtšenko artiklis “Праздник Аны’дялы у авамских нганасан" (Simtšenko 1963), mis põhineb 1961. aasta välitöö andmetel. Käesoleva uurimuse aluseks on nganassaani ringtantsu videosalvestus, mille autor on teinud 1989. aasta välitöödel Taimõri poolsaarel UstAvami külas.

Nganassaani tants on ringtants. Kui käsitleme tantsu liikumisena $8 / 8$ taktimõõdus (selle põhjal on liikumist kõige lihtsam selgitada), võime seda kirjeldada järgmiselt. Tantsu alustades seisavad tantsijad lähteasendis, parem jalg risti üle vasaku jala. Esimesel löögil laskuvad tantsijad põlvist alla (foto 1a). Teisel löögil tõusevad nad taas sirgetele jalgadele (foto 1b). Sama kordub kolmandal ja neljandal löögil. Tulemuseks on keha õõtsumine ülesalla. Viies löök on rõhulisem kui teised, ning sellel löögil tõugatakse vasak jalg maast lahti (foto 1c). Koos sellega viiakse küünarnukist kõverdatud käed ette. Samm hõlmab viiendat ja kuuendat lööki. Seitsmendal löögil sooritatakse külgsamm vasakule (päripäeva). See samm hõlmab seitsmendat ja kaheksandat lööki (foto 1d). Järgmisel (esimesel) löögil asetatakse parem jalg taas vasaku ette ning sama motiiv kordub.

J. Simtšenko andmetel on tegemist tantsuga, mis kuulus polaaröö lõppu tähistava pikema rituaali koostisse. 1980. aastatel seda tantsu autentses situatsioonis enam ei tantsitud, nagu ei toimunud ka ani'a d'aly rituaale. ${ }^{4}$ Tantsu, mis on järgneva analüüsi aluseks, esitati selleks, et näidata uurijatele, kuidas nganassaanid varem tantsisid. Ring koosnes Djulsõmjaku Kosterkini ${ }^{5}$ pereliikmetest. Lapsed polnud seda tantsu varem tantsinud ega isegi näinud. Kohmakad liigutused ning ilmselt ka tantsu saatvad ebatavalised häälitsused

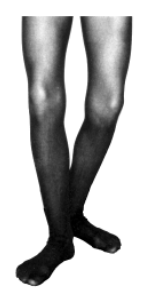

$1 \mathrm{a}$

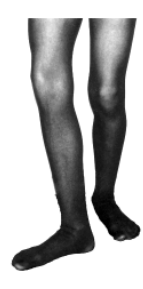

$1 b$

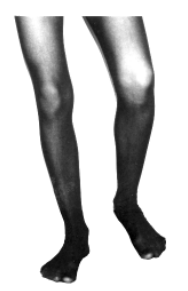

1c

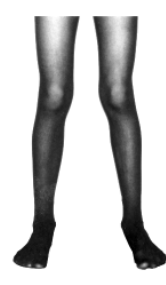

$1 d$

Foto 1. Nganassaani ringtantsu sammud: põlvenõtkutus (1a); tõus lähteasendisse (1b); lahtitõuge (1c); külgsamm (1d). Piret Voolaiu fotod. ${ }^{3}$ 
ajasid neid algul naerma. Kuid nähes, millise tõsidusega vanemad tantsu esitavad, taltusid ka vallatud lapsed ja püüdsid vanemaid hoolsalt matkida nii liigutuste kui ka häälitsuste osas. ${ }^{6}$

Tantsijad jäljendasid karu. D. Kosterkin kommenteeris tantsu järgmiselt:

See on meie rahvuslik tants - kõige rahvuslikum. See on karutants [nganassani k narka beters'a]. Karu seisab kahel jalal ja liigutab esikäppi. See pole tavaline tants, see tuleb šamaanilt. Abivaimud on ju karud. Aga me tantsime seda tantsu tegelikult ainult kevadel. Märtsis tuleb karu koopast välja. Ta on seal kogu talve olnud, pole end üldse liigutanud. Nü̈̈, kevadel, tahab ta liikuda.

Selliste rituaalidega tähistasid polaaröö lõppu või päikese nähtavale ilmumist paljud põhja väikerahvad. Näiteks nganassaanide lähimad naabrid dolgaanid nimetasid seda püha heiro (dolgaani keeles 'päike'). Rituaali koostisse kuulus kurgede pulmatantsu jäljendamine. Vormilt oli see nganassaani karutantsu sarnane ringtants. Liikumist saatsid kurgede häälitsusi imiteerivad helid, mis vaheldusid sõna heiro retsiteerimisega (Aleksejeva 2004: 260261).

Pidustuste korraldamise tava kevadtalvel on säilinud tänini, kuid need pole enam võõra pilgu eest varjatud rituaalid, vaid tavalised rahvapeod. Imiteerivad tantsud, kui neid seal üldse esitatakse, on muutunud stiliseeritud siberi tantsudeks, mis on küll ülimalt atraktiivsed, kuid loomulikult minetanud oma esialgse funktsiooni.

\section{Karutantsu saatemuusika}

Etnomusikolooge huvitab eelkõige tantsu muusikaline saade. 1989. aastal jäädvustatud karutantsu heliline saade koosneb vokaablitest ja kähisevatest kurguhäälitsustest. Vokaableid an-ti-na man-ti-na a-ku ai hääldatakse kõnelähedaselt, kuid nende helikõrgust on siiski võimalik kindlaks määrata. Iseloomustades vokaableid heli kvaliteedi seisukohalt, võime need paigutada kõne ja laulmise piirialale. Tantsusaate teine osa moodustub kähisevatest häälitsustest, mida korratakse kindlas rütmis. Nende ligikaudset kõla võime väljendada silpidega öo'-ö-ai. ${ }^{7}$

Vokaablite ja kurguhelide kasutamist tantsu saates on maininud juba A. Th. von Middendorff, kes iseloomustab viimaseid kui röhkivaid köhatusi (Middendorff 1953: 208-209, 1987: 127). Märksa konkreetsemat teavet pakub J. Simtšenko uurimus, millest võime lugeda järgmist. 1961. aastal läbi viidud rituaali käigus laulsid tantsu saateks ainult mehed. Meloodia koosnes kahest 
helist, mis moodustasid J. Simtšenko auditiivsete muljete kohaselt puhta kvindi. Kõrgemal helil imesid lauljad kopsudesse kähinal õhku ja alumisel helil hingasid röhatades välja (Simtšenko 1963: 173-174). J. Simtšenko on esimene uurija, kes peab mainimisväärseks fakti, et tantsu saade koosnes helidest, mida produtseeriti vaheldumisi sisse ja välja hingates. See on käesoleva uurimuse seisukohalt väga oluline tähelepanek.

Kui võrdleme A. Th. von Middendorffi ja J. Simtšenko tantsukirjeldusi 1989. aasta videosalvestusel põhinevate kirjeldustega, ilmneb, et tantsu liikumine on aja jooksul üha lihtsustunud. ${ }^{8}$ Ehkki tants on koreograafilises mõttes degenereerunud, on see siiski säilitanud spetsiifilise saatemuusika. Käesolevas uurimuses kasutatava materjali miinuseks võib pidada asjaolu, et tantsu ei tantsitud autentses situatsioonis. See jätab meid ilma võimalusest põhjalikult analüüsida neid muutusi, mis toimusid tantsijate käitumises tunde väldanud tantsimise kestel. Selles osas saame toetuda ainult varasemate uurijate vähestele tähelepanekutele. Kuid materjal on väärtuslik seetõttu, et meil on nüüd olemas tantsu saade salvestatud helidena, mida on võimalik erinevate meetodite abil analüüsida.

\section{Tämbrilised iseärasused}

Nganassaani tantsumuusika vokaablisegmentide kõlalised iseärasused ei ole käesoleva artikli seisukohalt olulised, küll aga on seda kähisevad helid. Meid huvitab kaks küsimust: (1) kuidas iseloomustada tämbrit, mis nende

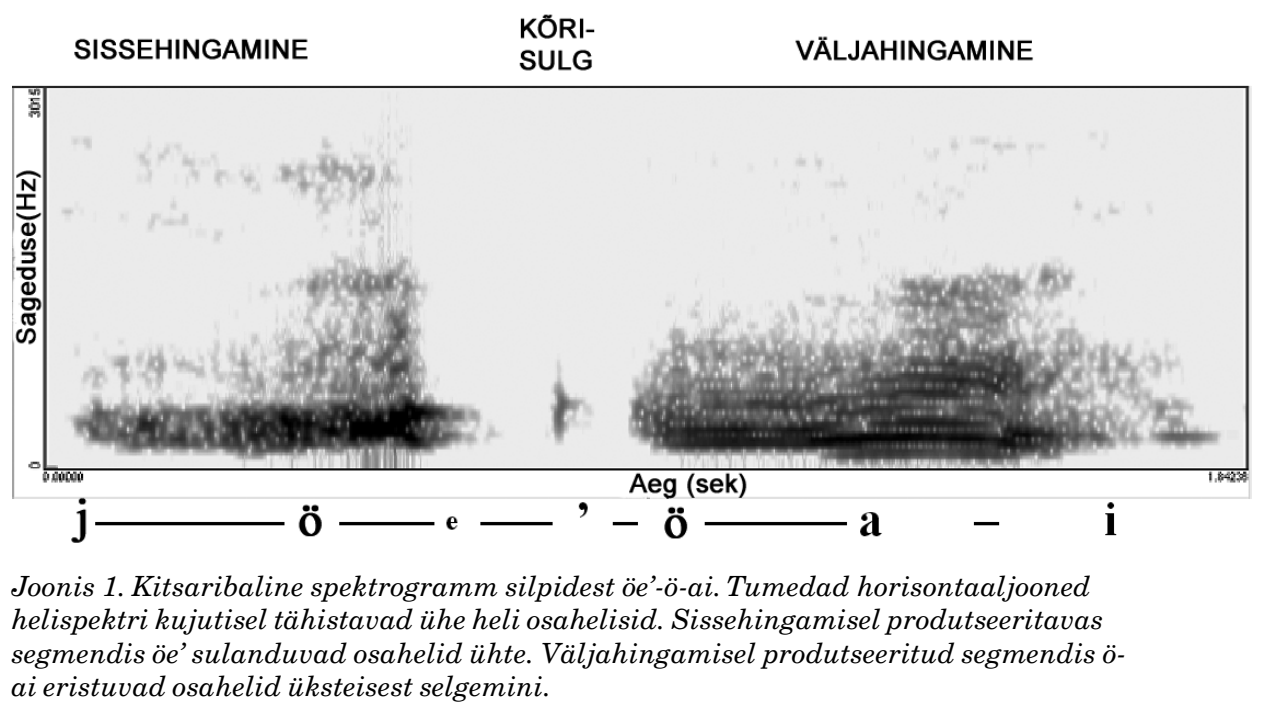


helide puhul on kahtlemata olulisem iseärasus kui konkreetne helikõrgus või rütm, ning (2) kuidas helisid produtseeritakse.

Kui tämbri kirjeldamise aluseks on auditiivne analüüs, siis on tulemuseks enamasti omadussõnaline tämbrimääratlus (nt kile, kahisev, kärisev vms). Lisavõimalus on kõnealuse tämbri võrdlemine mõne teise heliga, mille kohta eeldatakse, et see on üldtuntud. Mõlemad moodused on subjektiivsed, kuid aitavad siiski luua tämbrist mingit kõlalist kujutlust. Objektiivsemat informatsiooni võib meile anda nt heli spektraalanalüüsil põhinev foneetiline kirjeldus. Järgnev spektrogramm (joonis 1) demonstreerib heli kvalitatiivseid erinevusi silbis öe' võrrelduna silpidega $\ddot{o}$-ai. Silp öe' on kähinamotiivi esimene segment. Laulja toob selle kuuldavale õhku sügavalt kopsudesse sisse hingates. Seejärel katkestab hääle kõrisulg: valge ala spektrogrammil viitab heli puudumisele ehk vaikusele. Kõrisulule järgneb motiivi kolmas segment, mille kestel laulja hingab välja nagu tavalise kõne või laulmise korral.

Spektraalanalüüsi tulemuste põhjal võime ütelda, et sissehingamisel tekkiv heli sarnaneb müraga. Müra ei ole muusikaline heli: sel puudub täpselt määratletav kõrgus. Väljahingamisel tekkiv heli on mööndustega kirjeldatav laululise helina, sest selle struktuuri võib nimetada perioodiliseks (st perioodiliselt korduvaid osahelisid, mida spektrogrammil kujutavad tumedamad horisontaaljooned, on võimalik üksteisest eristada). Kokkuvõtteks võime ütelda, et tantsusaade sisaldab motiivi, milles on ühendatud müraefekt ja poollaululine intonatsioon. ${ }^{9}$

Veelgi täiuslikuma pildi heli olemusest saame siis, kui teame, kuidas heli tekitatakse. Järgnev kirjeldus põhineb eksperimendi käigus kõnealuse vokaaltehnika omandanud Allan Vurma ${ }^{10}$ selgitustel selle kohta, kuidas ta oma hääleorganeid kasutas.

Glotis on parasjagu nii avatud, et häälele lisandub kahin. Mida suurema avaga on glotis, seda vähem kuuldub kahinat. Tavalise sissehingamise puhul hoitakse häälepaelad täiesti lahti. Kõrikähina produtseerimisel on häälepaelad teatud mõttes hingamisasendis, kuid paiknevad teineteisele siiski suhteliselt lähedal, seega - häälepaelad on poolavatud.

Õhu tungimist läbi glotise võib iseloomustada kui kaootilist turbulentsi. Kuna tegemist on ingressiooniga, siis puhutakse õhku hä̈̈lepaeltele teistpidi kui tavalisel laulmisel või kõnelemisel. Häälepaelte alla tekitatakse hõrendus: kopsumaht suureneb ning õhu tihedus väheneb. Välisõhk voolab kopsu, kuid kuna glotis on poolavatud, siis tekibki õhuturbulents, mida tavalise hingamise korral ei esine. Kogu 
kähinamotiivi kestel liiguvad häälepaelad laiast asendist kuni kõrisuluni.

Kõrikähinale on iseloomulik n-ö pigistatud kõla. See on saavutatav ebahäälepaelte kasutamisega. ${ }^{11}$ Ebahäälepaelad puutuvad teineteisega kokku juhul, kui kõri kitsaks pigistada. Kõrikähina puhul ei saa pigistamine siiski olla ekstreemselt tugev. Kuna ebahäälepaeltel puudub lihasstruktuur, siis on võnkumine kaootiline ehk aperioodiline, mistõttu pole võimalik tekitada konkreetse kõrgusega heli.

Esitame võrdluseks Djulsõmjaku Kosterkini kommentaari samade helide kohta:

Algul on mul tavalise häälega öeldud sõnad "öe’-ö-ai”. Siis ma lisan neile kähina [demonstreerib õhu sisseimemist]. Nü̈d minu kõri justkui neelaks hääle oma sisemusse [luksatab]. Pärast seda ma lasen ôhu jälle välja.

Selgitusi võrreldes näeme, et need kirjeldused - üks muusikateoreetiline ja teine tavakeelne - on teineteisega üldjoontes sarnased.

\section{Tantsusaate polüfunktsionaalsusest}

Mis on tantsusaate otstarve? Sellele küsimusele võib anda erinevaid vastuseid. Esiteks, iga tants vajab mingit muusikalist saadet, sest see aitab korrigeerida tantsijate liikumist. Kuid miks saadavad tantsijad oma liigutusi just kähiseva helindiga? Siin peame kõigepealt mainima tantsu seost karu imiteerimisega. Nganassaanid nimetavad tantsu karutantsuks. Informantide selgituste kohaselt jäljendatakse karu nii liigutuste kui ka häälitsustega.

Vokaaltehnika, mis põhineb vaheldumisi sisse ja välja hingates produtseeritud helidel, on pooluselähedases kultuuripiirkonnas laialt levinud. Seda kasutavad nii korjakid, evengid, eveenid, tunguusid kui ka tšuktšid jt Siberi rahvad, samuti inuitid. Oletatavasti on inuitid siirdunud üle Beringi väina Aasiast Ameerikasse, viies Jean-Jacques Nattiez' arvamuse kohaselt kaasa kõnealuse vokaaltehnika protovormid. Nende protovormide alusel on välja kujunenud erinevad žanrid: inuitidel kõrimängud, Põhja-Siberi rahvastel aga tantsumuusika. Tantsumuusikat ja kõrimänge seob ühine maagiline funktsioon. Kõrikähina abil jäljendati karusid, põtru, hülgeid, ronki, rabakanasid, kurgi jt loomi ning linde. See fakt, samuti inuiti informantide ütlused kinnitavad, et kõrikähinaga seotud žanre on kasutatud jahiõnne mõjutamiseks (Nattiez 1999: 405). 


\section{Dhikri praktiseerimine islamimaades}

Kõrikähinad on lisaks traditsioonilistele kütiühiskondadele levinud ka mujal. Samalaadset vokaaltehnikat tuntakse nt islamimaades. Kontekstuaalse ühisjoonena torkab silma asjaolu, et nii pooluselähedases piirkonnas kui ka islamimaades on see seotud mingi rituaalse tegevusega.

Sisse- ja väljahingamisel põhineva vokaaltehnika kohta leiame palju näiteid Gilbert Rouget' raamatust Music and Trance. A Theory of the Relations between Music and Possession (Rouget 1985; prantsuskeelne esmatrükk 1980). G. Rouget võrdlev uurimus annab ülevaate selle erilise hingamismooduse seosest rituaalse tegevusega maailma eri paigus, mainitakse ka Siberit. Juba raamatu pealkiri viitab sellele, et hingamistehnikal võib olla seos transiseisundiga. See seos on eriti selgesti esile toodud peatükis "Music and Trance among the Arabs" seoses religioosse praktikaga, mida nimetatakse dhikriks.

Sõna dhikr tõlgitakse tavaliselt inglise keelde 'recollection', eesti keeles võiksime seda määratleda kui meelespidamist. Dhikri sisu seisneb jumaliku nime kordamises, selleks et mäletada jumalat ning samas panna teda mäletama kellegi olemasolu, eeldades, et nii saab see inimene õnnistuse osaliseks.

Dhikri praktiseerivad derviši vennaskonnad. Rituaal kulgeb kaheastmeliselt. Selle algupoolel dervišid istuvad, õõtsutavad ülakeha ja laulavad samal ajal palveid. Kui rituaali esimeses pooles kulgeb muusikaline tegevus organiseerimatult, siis rituaali teises pooles koondub kogu tegevus rütmiliselt retsiteeritava teksti ümber. Mehed tõusevad püsti, hoides üksteisel kätest või õlgadest, ning alustavad aeglast liikumist. Vaheldumisi hüüetega $h a-h i$ korratakse poollauldes Allahi nime. Kujuneb kindel rütm, mille aluseks on liialdatult intensiivne sisse- ja väljahingamine.

Tämber, mis tekitatakse kurgu tagaosas, kõlab rämedalt. Heliline efekt saavutatakse spetsiaalse tehnika abil, mille algus ulatub 12. sajandisse. Seda on kirjeldatud nii: silbil ha hingatakse väga sügavalt sisse ja silbil $h i$ hingatakse välja nii madalalt kui võimalik. Hääl on kirjeldatav kahiseva krigina või käginana.

Sellise helilise tegevuse rütmis tantsitakse, painutades kaela vasakuleparemale või ette-taha. Tantsijad moodustavad erinevaid figuure (enamasti ringe) ning liiguvad aeglaselt tammudes. Lõpuks jõuab tegevus paroksüsmi: higiste nägude ja poolsuletud silmadega mehi tabab rütmiline hullus ja sellele järgneb vaikus: kollektiivne transs on saavutatud.

Etnoloogid ja antropoloogid, kes on dhikri tantsimise juures viibinud ning selle kulgu kirjeldanud, on veendunud, et hingamistehnikal on oluline tähtsus 
transi saavutamisel. Kirjeldustest on järeldatud, et mitu tundi vältav pulmonaarne hüperventilatsioon võib esile kutsuda teatud füsioloogilisi reaktsioone, nt peapööritust. Lisaks sellele võib häälepaelte hüperaktiivsus põhjustada kuulmissüsteemi ülestimuleerimist. See tuleneb vibreerimisest kõris, mis levib sisemisi kanaleid pidi ning omab kahtlemata kaasmõju vaskulaarse ja neuroloogilise tasakaalu muutumisele ajus.

G. Rouget' andmetel ei ole dhikri toimemehhanisme kunagi (meditsiini)teaduslikult uuritud, eelnenu on vaid kokkuvõte meedikute arvamustest. Arvamuste aluseks on dhikri kirjeldused, mis saadud antropoloogidelt ja etnoloogidelt, kuid on tõenäoline, et meditsiiniteadlaste seisukohad on inspiratsiooni saanud $\mathrm{ka}$ araablaste endi traditsioonilis-teoreetilistest seisukohtadest, mis on järgmised.

Muusika funktsioon dhikris on inimkeha erinevate keskuste aktiveerimine. Seda soodustab akustilise energia ringlemine, rütmi tajumine ja vibratsiooni teadvustumine. Dervišid teavad (ehkki selle teadmise päritolu oleks raske seletada), et kõris paikneb närvilõpe, mille olemasolu on tähtis hingele. Et hääle tekitamine puudutab otseselt närvilõpme asupaika, kujuneb muusikalisele rütmile allutatud hingamine võimsaks teguriks meelte kontrollimisel ja nende tegevuse reguleerimisel. Tähtsus, mida araablased omistavad närvilõpmele, võib G. Rouget' arvates viidata sellele, et laulmine on transi saavutamise protsessi esmane tegur.

Dhikr ei pruugi alati välja viia transiseisundini. Tulemus sõltub sellest, milliseid põhjuse-tagajärje suhteid selle praktiseerijad tunnustavad. Kui püüllused on teadlikult suunatud transi saavutamisele ja usutakse, et kui teatud tegevusele peab järgnema teatud tagajärg, siis see ka järgneb, ning vastupidi - kui eesmärgiks ei ole transiseisund, siis selleni ei jõuta. Seega, kui vennaskonnas aktsepteeritava mudeli põhjal on teatud muusikalis-tantsuline tegevus transi põhjustaja, siis see mudel ka realiseerub. Transivalmidus peab eksisteerima praktiseerija teadvuses või alateadvuses (st transsi jõudmine ei pruugi olla teadlik tegevus). Ühtlasi on oluline lisada, et dhikri praktiseerijad ei kasuta mingeid narkootilisi aineid, mis võiksid nende seisundit soovitud suunas mõjutada (Rouget 1985: 262-302).

\section{Karutantsu ja kollektiivse transi võimalikest seostest}

Araabia dhikri kirjeldusest tõusevad esile järgmised olulised jooned, mis on iseloomulikud samuti nganassaani karutantsule: (1) lihtne tantsuline liikumine toimub mõõdukas tempos; (2) tantsu saateks kasutatakse rütmilisel sisse- ja väljahingamisel põhinevat vokaaltehnikat. 


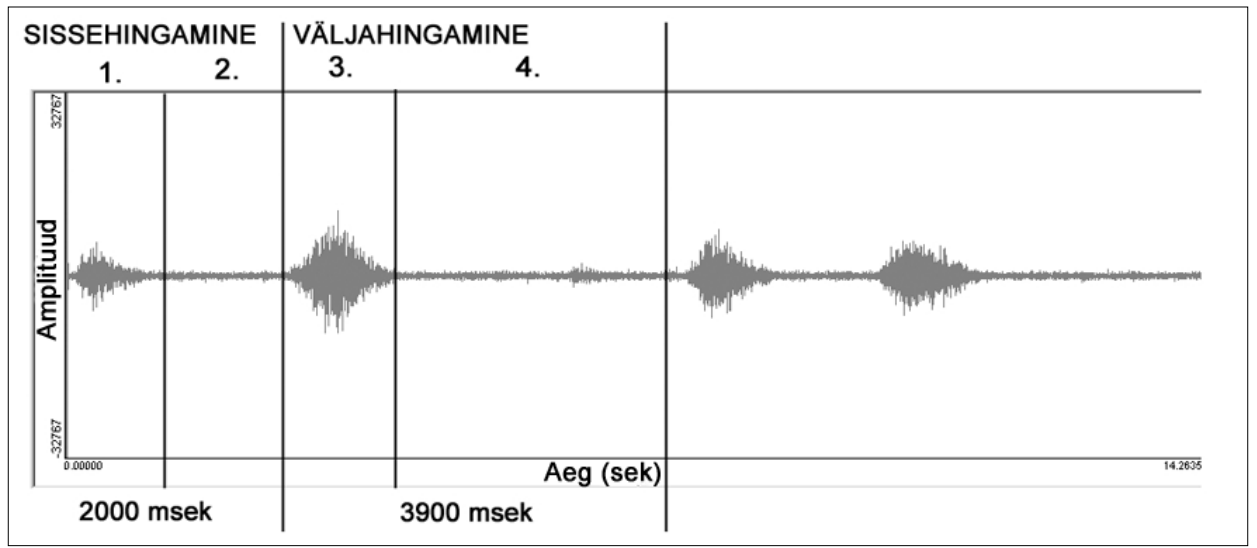

Joonis 2. Hingamistsüklite ostsillogramm (x-teljel amplituud, y-teljel aeg), mis kujutab hingamist rahuolekus. Hingamistsükkel on kahefaasiline, koosnedes sisse-ja väljahingamisest. Mõlema faasi lõpetab oklusioon: I faas = (1) sissehingamine, (2) oklusioon (õhuvoolu sulgus); II faas = (3) väljahingamine, (4) oklusioon.

Dhikri vokaaltehnikat seostatakse hüperventilatsiooniga, mille lõpptulemuseks võib olla transiseisund. Nganassaani karutants kuulub samuti rituaalse tegevuse juurde. Lisaks on J. Simtšenko maininud tantsijate kokkuvarisemist ning see fakt suunab meid oletusele, et tantsu eesmärgiks võis sarnaselt dhikrile olla kollektiivse transi saavutamine. Eelnev ajendasidki püstitama järgmist hüpoteesi: Nganassaani rituaalse tantsu ja musitseerimisega kaasnevad neuropsühholoogilised sümptomid on seostatavd hüperventilatsiooni ja hüpokapniaga.

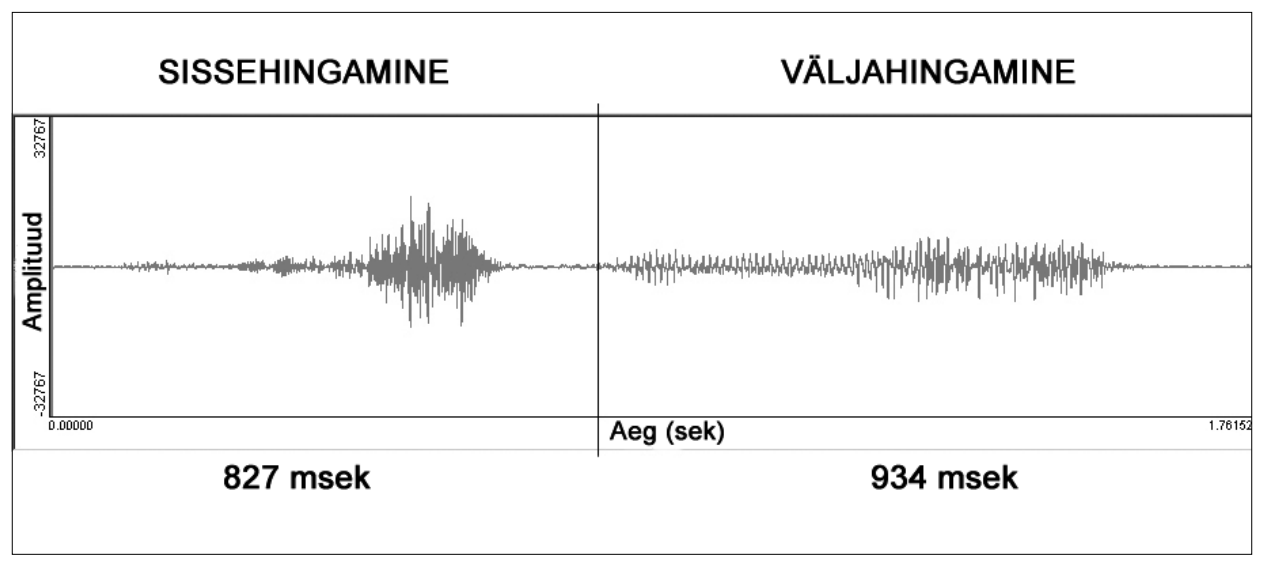

Joonis 3. Ostsillogramm nganassaani tantsusaate ühest hingamistsüklist. Ostsillogrammi poolitav ristkursor paikneb sisse- ja väljahingamise piiril. 
Hüperventilatsioon on kiire ning sügav hingamine, mis põhjustab süsinikdioksiidi järsku vähenemist veres.

Hingamine on tsükliline tegevus. Tavalise hingamistsükli võrdlemine tantsusaate hingamistsükliga toob hästi esile hüperventilatsiooni olemuse, mida võime tõdeda järgnevaid visualiseeritud tsükleid vaadeldes.

Joonis 2 kujutab n-ö tavalise hingamise kaht järjestikust hingamistsüklit. Hingamine helisalvestati ja salvestis sisestati heli akustilise analüüsi programmi, mis võimaldab teostada tsüklite mõõtmisi. Tulemus on esitatud ostsillogrammina. Helisalvestamise ajal viibis katseisik rahuolekus, sooritamata mingeid liigutusi. Hingamise helisalvestamise eesmärgiks oligi sellise hingamise visualiseerimine, millele pole mõju avaldanud välised tegurid (nt füüsiline koormus, kõrgendatud emotsionaalne seisund vms).

Hingamist rahuolekus iseloomustab faaside selline ajaline suhe, kus väljahingamine on peaaegu kaks korda nii pikk kui sissehingamine. Joonis 3 näitab, et karutantsu saates on tsüklite vahekord hoopis teistsugune.

Hingamist rahuolekus iseloomustas faaside ajaline suhe, kus väljahingamine on ligikaudu kaks korda nii pikk kui sissehingamine. Joonis 3 näitab, et karutantsu saates on tsüklid ligikaudu ühepikkused. Samuti näeme, et rahuolekus hingamise korral on väljahingamine tunduvalt intensiivsem kui tantsusaates (vt 3. segmendi amplituudi joonisel 2), kus olukord on vastupidine (vt 2. segmendi amplituudi joonisel 3). Seega on ostsillogrammi põhjal saadud informatsioon kooskõlas hüperventilatsiooni määratlusega, mille kohaselt hingamine on sügav. Nii oleme tantsusaate hingamises tuvastanud vähemalt ühe hüperventilatsiooni tunnuse.

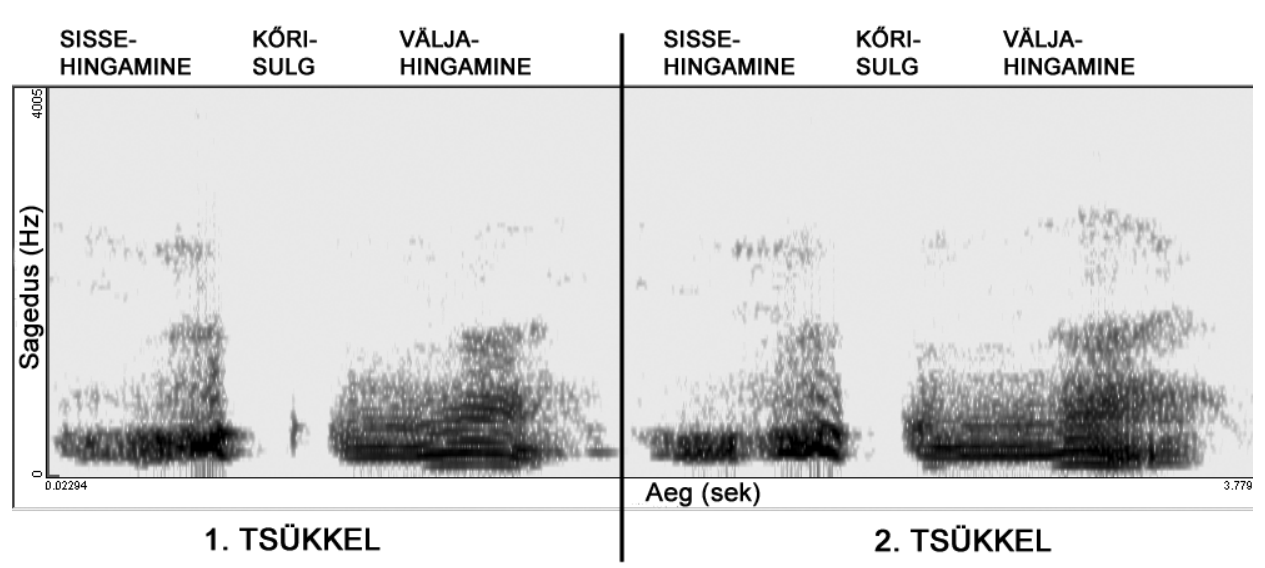

Joonis 4. Kitsaribaline spektrogramm karutantsu saatvast helindist. 1. segment produtseeritakse sissehingamisel, 3. segment väljahingamisel. Valged alad (segmendid 2 ja 4) näitavad heli puudumist ehk oklusiooni. Ristkursor paikneb kahte tsüklit poolitaval oklusioonil. 


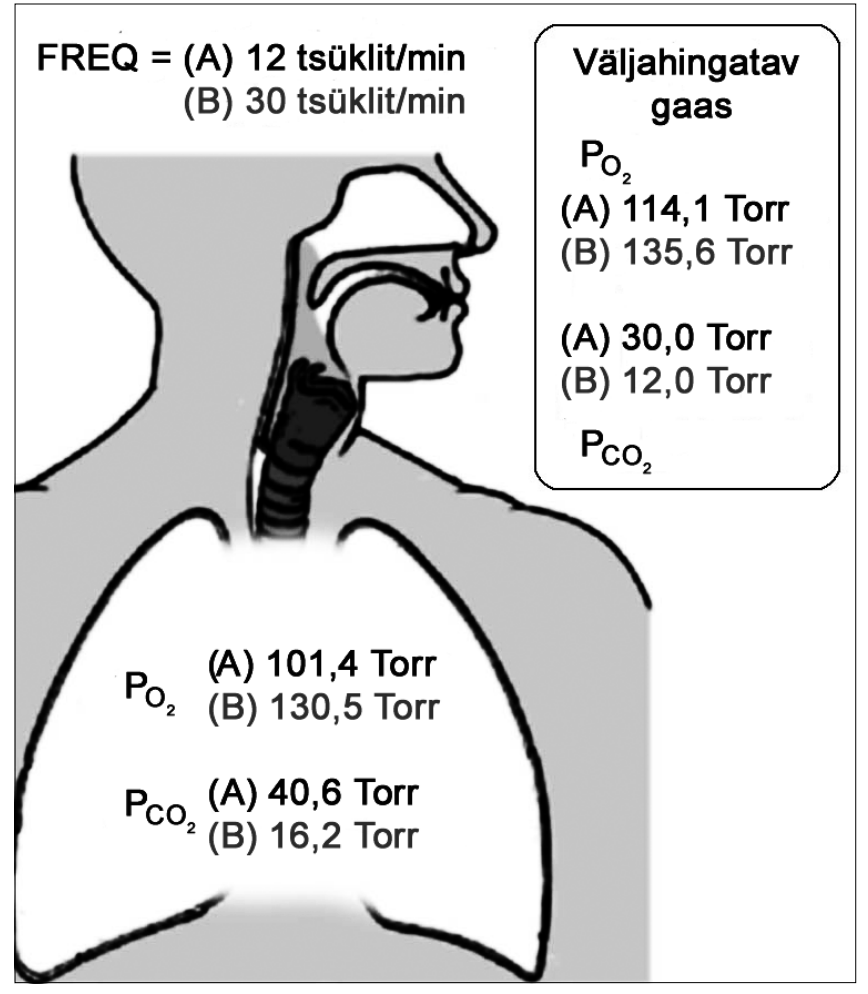

Joonis 5. (A)-andmed joonisel iseloomustavad tavalist hingamist, (B)-andmed iseloomustavad hingamist tantsusaates. FREQ

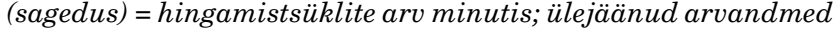
näitavad gaasirõhu muutumist torrides hingamise ajal.

Võrreldes hingamist rahuolekus hingamisega tantsimise ajal, ilmneb, et erinevad on ka väljahingamisfaaside oklusioonid. Rahuolekus hingamise korral on õhuvoolu sulgus pikk (vt 4. segmenti joonisel 2), kuid tantsusaate hingamistsüklis on see minimaalne. Tantsusaate puhul tuleb oklusioon selgemini esile kitsaribalise spektrogrammi vahendusel (joonis 4).

Joonis 4 näitab selgelt, et sissehingamisele järgnev sulufaas (2. segment) on pikem kui sulufaas kahe järjestikuse tsükli vahel. See on vastupidine olukord võrreldes rahuolekus hingamisega. Üks peamisi erinevusi normaalse hingamistsükli ja hüperventilatiivse tsükli vahel seisnebki väljahingamisele järgneva oklusiooni kestuses. Aktiivne hingamistegevus hüperventilatsiooni korral on peaaegu katkematu. Seega, hüperventilatsioon on võrreldav hingeldamisega.

Mida see teadmine meile annab? Tsükkel, mille struktuuri kuuluvad pikad oklusioonid, kestab kauem kui lühikeste oklusioonidega tsükkel. Järelikult 
on viimasel juhul hingamissagedus teatud ajaühikus suurem. Ehk teisisõnu, hüperventilatsiooni korral mahub ühte ajaühikusse rohkem hingamistsükleid kui tavalise hingamise korral.

Järgmise sammuna on meil võimalik välja arvutada alveolaarne gaasivahetus. Käesolevas uurimuses on selleks kasutatud vabavaraprogrammi Alveolar Gas Exchange.

Normaalse hingamise korral (A) on hingamissagedus 12 tsüklit minutis. Tantsusaates (B) on hingamissagedus 30 tsüklit minutis. Järelikult on tantsusaate puhul tegemist kiirenenud hingamisega. Seega oleme tantsuhingamise puhul tuvastanud hüperventilatsiooni teise peamist tunnuse: hüperventilatsioon on kiire hingamine.

Seoses andmetega, mida programm võimaldab saada gaasirõhu muutumise kohta, lisame, et kõige olulisem hüperventilatsiooni seisukohalt on süsinikdioksiidi languse ilmnemine. Süsinikdioksiidi langus käivitab teatud patofüsioloogilised protsessid veres ja ajus, mis on hüpokapnia eelsoodumuseks.

Võime käsitleda hüperventileerimist protsessina, mis on hüpokapnia sündroomi üheks põhjustajaks. Hüpokapnial on kolm peamist tunnust: paresteesia (vääraistingud, nt sipelgajooksutunne nahal), tetaania (lihaste hootised krambid) ning teadvuse kaotus. Meie oletuse kohaselt teevad nganassaanid imiteeriva tämbri saavutamiseks spetsiifilist hingamistehnikat kasutades ühtlasi ka midagi niisugust, mis võiks põhjustada vähemalt mõnda neist kolmest sümptomist. Mainigem siinjuures, et neis allikates, millele toetub G. Rouget, ei seostata hingeldamist hüpokapniaga - räägitakse vaid hüperventilatsioonist. Hüperventilatsioon on liighingamine ja seega tegelikult ainult soovitud seisundi saavutamise vahend. Seisundit, mille tantsijad saavutavad, võiks põhimõtteliselt võrrelda hüpokapniaga.

Transiseisundi saavutamiseks rituaalse tegevuse käigus on kahtlemata mitmeid võimalusi. Sageli kasutatakse selleks erinevaid drooge. G. Rouget rõhutab, et dhikri praktiseerijad drooge ei kasutanud. Puudutame seda probleemi ka seoses nganassaanidega.

On üldiselt teada, et Siberi traditsioonilistes kultuurides tuntakse kärbseseene hallotsinogeenset mõju. Mükofaagiaga on seotud nt neenetsi šamanism ${ }^{12}$ ning neenetsid on teatavasti nganassaanide lähimad kultuurisugulased. Neenetsid on seent kasutatud abivahendina šamaanirituaalides, kus šamaanil tuleb sooritada kujuteldav reis all- või ülailma, st tuleb jõuda seisundisse, mis kutsuks esile nägemuse teispoolsusest. Kuna seene rolli siberi šamanismis pole väga põhjalikult uuritud, ei saa me väita, et kõik reisid toimuvad seeneuimas ega ka seda, et ilma seent kasutamata pole sellised reisid teostatavad. 
Muude droogide kasutamise kohta Siberis andmed puuduvad, kuid šamaanid võivad rakendada ka teisi tehnikaid oma meeltega manipuleerimiseks. On tõenäoline, et mõni muu tehnika (hüperventileerimine kaasa arvatud) võib mingil põhjusel äparduda - seda enam, kui tulemuse saavutamiseks on vajalik psüühiline eelhäälestus, nagu näitab informatsioon dhikri kohta. Kuid seen, kui see kord juba on alla neelatud, toimib paratamatult, olenemata sööja soovist. Nganassaani kultuuris teadaolevalt siiski puudub kärbseseene kasutamise tava, mis kõrvaldab võimaluse, et esmatähtis roll transsi jõudmisel võiks olla hallotsinogeenil. See fakt pakub samuti toetust meie hüpoteesile, et transiseisundi saavutamisel - juhul, kui see seisund karutantsu tantsides üldse saavutati - oli oluline tegur tahtlik hüperventileerimine.

\section{Järelmõtteid}

Artikkel andis ülevaate uurimistööst, mis puudutab rituaalse tantsu ja transiseisundi võimalikke seoseid. Fakt, et tantsimise ja transiseisundi vahel eksisteerib šamanismis seos, on laialt aktsepteeritud; kinnitagem seda tsitaadiga Mircea Eliade ekstaasitehnika uurimusest: From the earliest times, the classic method of achieving trance was dancing (Eliade 1974: 451). Niisiis pole teema iseenesest uudne, ehkki konkreetselt siinkirjeldatud tantsuga seoses pole varem transiseisundi saavutamise probleemi tõstatatud.

On olemas mitu võimalust, kuidas tants transiseisundi saavutamisele kaasa aitab. Neist peamine on kahtlemata rütmiliste liigutuste sooritamine üha kiirenevas tempos. Mis puutub nganassaani karutantsu, siis püsib see mõõduka tempo piires algusest lõpuni. Juhul, kui tantsimise kaudu tõepoolest sooviti jõuda transiseisundini, tuleb põhjusi otsida mujalt.

Transiseisundi saavutamisele võib mõju avaldada spetsiifiline hingamistehnika, kus sügav sissehingamine vaheldub väljahingamisega kindlas rütmis ning mis on kiirem tavapärasest hingamisest. Uurimused islami dhikri kohta pole küll teadusliku tõestamiseni jõudnud, kuid kuna ka araablaste n-ö traditsiooniline dhikri-filosoofia toetab seda arvamust, on kahtlusteks jäänud vähe ruumi. Hüperventilatsiooni efekti teadlikku kasutamist nganassaani traditsioonilises kultuuris pole tänapäevase välitöömaterjali abil enam võimalik tõestada ja sellist traditsionaalset transsijõudmise seletust nagu araablastel pole nganassaanidel kahjuks pakkuda.

Hüperventileerimine võib viia kokkuvarisemiseni või teadvuse kaotuse$\mathrm{ni}$ - see ei vajagi tegelikult enam tõestamist, sest meditsiiniteadus on selle juba ammu tõestanud. Pole tähtis, kas see leiab aset seoses paanikahoo või tantsimisega. Pigem vajab äraseletamist näiteks see, kuidas on võimalik teadvuse kaotust edasi lükata. Kõigis allikates rituaalsete tantsude kohta 


\section{Triinu Ojamaa}

märgitakse, et need kestsid kaua, kuid haigushoogude puhul ei ole kindlasti tegemist tunde vältava hingeldamisega. On võimalik, et kokkuvarisemise saabumist hoitakse kontrolli all dhikris Allahi nime kordamise ja nganassaani tantsus vokaablite retsiteerimisega, st vaheldumisi sooritatakse tegevusi, millest üks on suunatud teadvuse kaotamisele, teine aga pärsib seda, võimaldades lõõgastumishetki. Lahenduse sellele probleemile võiks ehk anda ainult situatsiooni modelleerimine, mille käigus arvestataks kõigi tegurite (tantsijate vanuse, soo, kaalu, pikkuse ja füüsilise koormuse, aja, organismis hüperventileerimise poolt põhjustatud protsesside jne) vastastikust toimet.

G. Rouget avaldab oma raamatus kahetsust, et tänapäeval saadav materjal rituaalsete tegevuste kohta pole enam autentne - see on nagu kohustuslik refrään, mis saadab peaaegu kõiki etnomusikoloogilisi uurimusi. Kuid olukorda võib hinnata ka teisiti. Esiteks, kui traditsioon alles funktsioneeris oma loomulikus keskkonnas, poleks teadlastel nagunii olnud võimalik seda jäädvustada. Kui tuua näiteks nganassaanid, siis J. Simtšenko järgi ei soovinud nad pööripäevarituaali juures näha isegi oma küla teistest rahvustest elanikke, rääkimata veel kaameratega võõrastest. Teadet kombetalituse toimumisest levitati salaja sõnumitooja vahendusel, kes kandis seda ühest nganassaani perest teise. Pigem tuleks väärtuslikuks pidada mis tahes tingimustes salvestatud materjali rituaalsete tantsude kohta. Meil on nüüd olemas videosalvestis, mis võimaldab saada andmeid nii tantsulise kui helilise tegevuse kohta. Neid aluseks võttes saaksime soovi korral teostada eksperimentaalseid mõõtmisi hüperventilatsiooni efekti modelleerimise huvides.

\section{Kommentaarid}

1 Artikkel põhineb osaliselt autori ja meditsiinidoktor Jaak Aru ühisuurimusel hüperventilatsioonist, mida on toetanud Eesti Teadusfondi grant nr 5118 "Heli akustilise analüüsi rakendamine etnomusikoloogias".

${ }^{2}$ Eesti keeles on Aili ja Ott Kursi tõlkes ilmunud raamat Reis Taimõrile (Middendorff 1987).

3 Artiklis kasutatud fotod ja joonised pärinevad Triinu Ojamaa ja Jaak Aru (2005) internetis Montrealis 10.-12. märtsini 2005 peetud rahvusvahelise interdistsiplinaarse musikoloogiakonverentsi (CIM05) avaldatud konverentsiettekandest "Can Hyperventilation be a Trance Mechanism in Nganasan Ritual Dance Accompaniment?"

${ }^{4}$ Vt J. Simtšenko uurimust, mis sisaldab põhjalikku ülevaadet kogu ani'a d'aly ('suur päev') rituaalist. Ohverdamine maa- ja mee-emale ning tantsimine olid rituaali kesksed tegevused (Simtšenko 1963).

5 Djulsõmjaku Kosterkin on nganassaani informant, kellelt pärineb nii peamine kontekstuaalne informatsioon tantsu kohta kui ka helisalvestatud tantsusaade, mida on kasutatud spektraalanalüüsi tegemisel. 
6 Videokatkend (OJAMAA_T_video.mjpg), pakituna koos helinäidetega zip.formaati, on võimalik vaatamiseks maha laadida internetist Montrealis 10.-12. märtsini 2005 peetud rahvusvahelise interdistsiplinaarse musikoloogiakonverentsi (CIM05) koduleheküljel asuvalt ettekannete loetelust (Aru \& Ojamaa 2005: sounds; http:// www.oicm.umontreal.ca/cim05/actes_en.html).

7 Esimene silp öe' lõpeb larüngaalklusiili ehk kõrisuluga.

8 Järeldus on tehtud Djulsõmjaku Kosterkini ja Faina Turdagina tantsimise põhjal, kes tõepoolest oskasid tantsida ja õpetasid ka lapsi, kelle liigutused olid algul n-ö kobavad ja hiljem lihtsalt lohakalt sooritatud.

9 Kõnealuse motiivi põhjalikku foneetilist analüüsi ja üksikasjalikumat interpretatsiooni sisaldab artikkel “Throat Rasping: Problems of Visualisation” (Ojamaa 2005).

${ }^{10}$ Allan Vurma on Eesti Filharmoonia kammerkoori laulja ja ühtlasi ka Eesti Muusika- ja Teatriakadeemia vokaalmetoodika õppejõud.

${ }^{11}$ Ebahäälepaelu kasutavad sageli jazz-ja rocklauljad. Nende paiknemist vt nt Oxfordi Ülikooli foneetikalaboratooriumi kodulehel John S. Colemani kirjutises leiduvalt jooniselt "The vocal tract and larynx" (http://www.phon.ox.ac.uk/ jcoleman/larynx_ coronal.GIF).

${ }^{12}$ Lähemalt vt nt CD Discovering Siberia: Songs of the Forest Nenets plaadilisast (Mägi \& Ojamaa \& Toulouze 2002). Plaadil on ka kärbseseenelaule, mis kuulusid selliste rituaalide struktuuri, kus šamaan kasutas kärbseseent.

\section{Kirjandus}

Aleksejeva 2004 = Алексеева, Галина. Хэйро - журавлиная песня долган. Музыка и ритуал: структура, семантика, специфика. Новосибирск: Новосибирская государственная консерватория им. М. И. Глинки, Римский университет “ТОР ВЕРГАТА”, lk 260-268.

Eliade, Mircea 1974. Shamanism: Archaic Techniques of Ecstasy. Bollingen Series 76. Princeton: Princeton University Press.

Middendorff, Alexander Theodor von 1953. Auf Schlitten, Boot und Rentierrücken. Sammlung "Volk und Buch". Leipzig: VEB F. A. Brockhaus Verlag.

Middendorff, Alexander Theodor von 1987. Reis Taimõrile. Tallinn: Eesti Raamat.

Mägi, Kaur \& Ojamaa, Triinu \& Toulouze, Eva 2002. Discovering Siberia: Songs of the Forest Nenets. CD koos tekstilisaga. Tartu: Eesti Kirjandusmuuseum.

Nattiez, Jean-Jacques 1999. Inuit Throat-Games and Siberian Throat Singing: A Comparative, Historical and Semiotical Approach. Ethnomusicology 43: 2, lk 399-418.

Ojamaa, Tiinu 2005. Throat Rasping: Problems of Visualisation. The World of Music 47: 2: Notation, Transcription, Visual Representation, lk 55-70.

Ojamaa, Triinu \& Aru, Jaak 2005. Can Hyperventilation be a Trance Mechanism in Nganasan Ritual Dance Accompaniment? Proceedings of the Conference on Interdisciplinary Musicology (CIM05): Actes du Colloque interdisciplinaire de musicologie (CIM05): Montréal (Québec) Canada, 10-12/03/2005. CD (vt ka www.oicm.umontreal.ca/cim05/cim05_articles/OJAMAA_T_CIM05.pdf - 20. oktoober 2006). 
Triinu Ojamaa

Rouget, Gilbert 1985. Music and Trance: A Theory of the Relations between Music and Possession. Chicago \& London: The University of Chicago Press.

Simtšenko 1963 = Симченко, Юрий. Праздник Аны’о-дялы у авамских нганасан. Сибирский этнографический сборник. V. Москва: Издательство Академии Наук CCCP, lk 168-179.

\section{Summary}

\section{Manifestation of Hyperventilation in Ritual Dances}

Triinu Ojamaa

Key words: hyperventilation, ritual dances, traditional Nganasan culture

We have a video recorded by the author on the Taimyr Peninsula (1989). It is the Nganasan bear dance demonstration, which did not take place in its traditional context, and therefore lasts only for about 15 minutes. In authentic situation the Nganasans performed their dance after a sacrificial rite occurring at the commencement of the polar day. Not a single person could leave the circle of dancers: they had to continue until they collapsed. We also use the descriptions of round dances of Nganasans in North Siberia, documented in 1884 (Middendorff 1956), in 1961 (Simchenko 1963) and in ... (Ojamaa 2002).

An overview of the musical accompaniment to the dance, consisting of rasping sounds to imitate the roaring of a bear, is presented by the three authors. Besides the specific timbre, an essential feature of such accompaniment is a frequent rhythmic respiration.

The descriptions and spectral analysis indicate that the sound quality of the accompaniment is similar to that of Dhikr. Dhikr is a religious practice known in Arab countries which involves slow dancing accompanied by a specific sound (described as panting and/or roaring). The breathing technique has been defined as hyperventilation, and may cause dizziness, as vibration modifies the vascular and neurological balance of the encephalon. This may result in trance (Rouget 1985).

Based on the information given above, we propose the following hypothesis:

Neuropsychological symptoms in Nganasan ritual dancing and music making are related to the effects of hyperventilation (and hypocapnia). Vibration caused by specific imitative timbre may be an additional component to attain various psychodynamic effects.

In ritual practice, dance serves as a medium for falling into the state of trance. It is usually caused by a gradually escalating tempo. In Nganasan dance the tempo remains moderate. Thus we argue that tempo is not the most important factor. Nganasans may have fallen into a trance with the help of breathing. A specific respiratory technique is also important in terms of imitative timbre. Capturing a desired timbre is connected with a specific respiratory technique. We can define it as controlled breathing similar to hyperventilation. Hypocapnia resulting in hyperventilation explains certain features of trance (fainting) in the Nganasan religious ritual. 